\title{
Engine Based Trigeneration with Thermal Storage
}

\author{
Mahesh Shelar $^{\dot{\mathrm{B}}}$, V.K. Patil ${ }^{\dot{\mathrm{B}} *}$ and G.N. Kulkarni ${ }^{\dot{\mathrm{A}}}$ \\ ${ }^{\dot{A}}$ Department of Mechanical Engineering, College of Engineering Pune Maharastra India \\ ${ }^{\dot{B}} \mathrm{~K}$ K Wagh Institute of Engineering, Education and Research, Panchavati Nashik.422003. Maharastra India
}

Accepted 10 January 2014, Available online 01 February 2014, Special Issue-2, (February 2014)

\begin{abstract}
Diesel Generators are widely used in India in applications like hospitals and hotels where reliable power supply is important. Anecdotal evidence suggests that diesel generators are selected to meet the peak essential loads of the users without consideration of waste heat recovery. Diesel generators utilized with heat energy driven vapour absorption machines and waste heat recovery hot water generator (Trigeneration) can meet electricity, cooling and heating demand. Different configurations of engine based trigeneration are possible. The paper discusses a configuration of engine based trigeneration system with thermal storage that could be applied to places where simultaneous electricity, cooling and power demand exists. The physical model, mathematical model and operating strategy based on storage tank temperature for the proposed trigeneration system are presented.
\end{abstract}

Keywords: heat recovery, cogeneration, Trigeneration.

\section{Introduction}

Combined heat and power (cogeneration) and combined heat, cooling and power (trigeneration) are useful techniques for reducing fossil energy consumption. Cogeneration has been around for more than fifty years especially in developed countries and considerable experience exists as regards design or selection of its components as well as its operation. Trigeneration on the other hand is a recent addition to the technique of energy conservation Trigeneration that is combined electricity, heat and cooling energy production is being increasingly adapted thanks to the commercial availability of absorption chillers.

The plant components of trigeneration system primarily include a prime mover, waste heat recovery boiler and vapour absorption system. Thus the Trigeneration systems could be classified based on the prime mover used. They could be studied from the application perspective, civil or industrial. Moreover choice of absorption system whether ammonia-water or lithium bromide system could influence whether the system is applied for freezing/preservation or comfort air conditioning applications. Internal Combustion engines, Turbo generators or fuel cells could be the options. Natural gas engines are commonly used. One reason for the choice of internal combustion engines over gas turbines is the efficiency values especially in the range of loads for hospitals (few hundreds kWe to few MWe capacity ) Small gas turbines are less efficient than internal combustion engines. Another reason is a common practice

*Corresponding author: Mahesh Shelar

DOI: http://dx.doi.org/10.14741/ijcet/spl.2.2014.76 of adopting engine based standby prime mover in hospitals to cater to emergency or scheduled blackouts. Retrofitting these systems with chiller and waste heat recovery boiler could be an immediate solution if grid electricity becomes dearer.

The chosen mode of heat recovery from internal combustion engines could be from exhaust gases and from water cooling jackets. The arrangement could be recovery at two different temperatures. Exhaust gas energy is utilized in waste heat recovery boiler to generate steam which drives absorption chiller. This indirect arrangement has an advantage of alternatively using steam for satisfying thermal demand but requires additional investments. The arrangement of driving chiller could be direct where the exhaust gases enter the generator section of chillers .Lithium Bromide-water absorption chillers are widely adopted chillers and a preferred choice for airconditioning applications. Double effect absorption chillers have better coefficient of performance than their single effect counterparts. The heat recovery from jacket water is at lower temperatures. Both thermal and cooling energy demands could be met through heat exchangers or chillers.

Some Authors (Bassols et al,2002) describe several Trigeneration systems installed in Scandavian countries. Two gas engines(totalling $4 \mathrm{MW}$ ) with ammonia water system for vegetable freezing facility in Spain, three gas engines with $9 \mathrm{MW}$ total capacity installed in a dairy factory in Burgos, Spain and two gas engines of 9MW total capacity installed in the meat factory of the same country with refrigeration capacity of $2500 \mathrm{~kW}$ are described. Small scale systems of few kWe capacities are also discussed in literature. A gas engine mini-CHP unit 
$(5.5 \mathrm{kWe})$ with an ejector cooling cycle is discussed in literature (Godefroy et al, 2007). Laboratory investigations on small diesel engine $(9.5 \mathrm{kWe})$ based electrolux absorption refrigeration systems are reported. Microtrigeneration systems are analyzed and reported in literature (Gluesenkamp et al 2013).A 10MWe natural gas fuelled Trigeneration systems are analysed by researchers stating the fact that natural gas engines are available in 1-3 MWe capacities (Colonna et al 2003). Similarly an analytical treatment is attempted by considering an 1900 $\mathrm{kW}$ natural gas fired engine with water-LiBr system of $1130 \mathrm{~kW}$ refrigeration capacity( Temir et al 2004 ).

Microturbines reportedly have lower $\mathrm{NO}_{\mathrm{X}}$ emissions than reciprocating engines and are well adapted to variety of fuels unlike engines.They can be used with double effect chillers. There exhaust temperatures of about $450-550^{\circ} \mathrm{C}$ makes them attractive for cogeneration and Trigeneration applications. The Power generation of microturbines is in the range of 25 to $250 \mathrm{~kW}$. They however have poor part load efficiency. Such a system and its thermodynamic analysis is included in literature(Huicochea et al, 2011) Large Scale Gas Turbines as a prime mover for Trigeneration systems are also reported.(Bassols et al,2002 )The study is about a gas turbine of capacity $5 \mathrm{MW}$ coupled to a $1400 \mathrm{~kW}$ absorption chiller installed in a Magarine factory in Netherlands. Gas turbine based trigeneration systems are therefore analysed rigorously ( Ziher et al 2006). These authors consider a $4570 \mathrm{~kW}$ Gas turbine coupled to $2 \mathrm{MW}$ absorption chiller for analysis. Hypothetical engine driven systems are also considered for modelling and simulation (Teopa et al 2005) Engine based trigeneration system are analysed and a selection strategy discussed but without thermal storage(Shelar et al 2009) . We find most of these studies proposing physical systems comprising of some prime mover and absorption chiller but without thermal storage. Systems without storage are feasible if the prime mover is grid connected and cooling and heating demand are continuous. Incorporating thermal storage can take care of variation in cooling and heating demand (which is the scope of the present paper) though variation in electric demand would require another strategy(not discussed in this paper)

\section{Proposed Physical Model of Trigeneration system}

The proposed trigeneration system would comprise of diesel generator, exhaust heat recovery unit, hot water storage. The water to be circulated in the engine jacket and exhaust gas heat recovery unit is stored in the hot water storage. All the components of trigeneration system are standardized and commercially available.

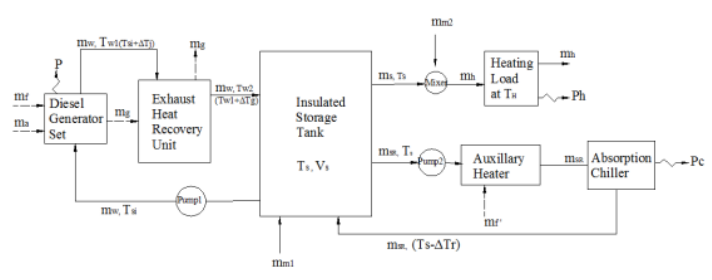

Figure 1.Schematic of proposed Trigeneration system with storage
The vapour absorption machine is a hot water operated Lithium bromide- water machine and is available from capacities ranging from 40 TR to $1200 \mathrm{TR}$. The hot water temperature entering and exiting the absorption chiller generator should be $90.6^{\circ} \mathrm{C}$ and $85^{\circ} \mathrm{C}$ respectively as per the manufacturer's specifications.

\section{Mathematical Model of Trigeneration system}

The mathematical model is based on thermodynamic principles and is valid for design as well as off design conditions (part load conditions of diesel generator and absorption machine). The mathematical model input are diesel generator parameters, the flow rates and hot water generator temperature parameters of absorption. The model calculates the storage tank temperature for given time interval. The operating strategy of the proposed system based on storage temperature is discussed based on which the duration of the system in cogeneration cooling mode and trigeneration mode can be calculated. An alternative strategy to operate the system at near steady storage temperature is also presented.

For Diesel generator (DG),the mathematical model calculates the rise in jacket water temperature from equation 2 which is obtained from energy balance model for the generator set both for full load and part load.(eq 1a and 1b).The input parameters are the mass flow rate of water, rated power output, corresponding fuel consumption and flue gas temperature at the rated output. For off design conditions, it is important to have information on how this parameters vary with load. Once the temperature rise ' $\Delta \mathrm{t}_{\mathrm{j}}$ ' is calculated, the $\mathrm{t}_{\mathrm{w} 1 \mathrm{R}}$ can be obtained.

Mathematical model for Rated Condition

$\mathrm{m}_{\mathrm{f}} * \mathrm{CV}=\mathrm{P}_{\mathrm{R}}+\mathrm{m}_{\mathrm{w}} \mathrm{C}_{\mathrm{pw}}\left(\mathrm{t}_{\mathrm{w} 1}-\mathrm{t}_{\mathrm{si}}\right)+\mathrm{m}_{\mathrm{g}} \mathrm{C}_{\mathrm{pg}}\left(\mathrm{t}_{\mathrm{g}}-\mathrm{t}_{\mathrm{a}}\right) \quad---1 \mathrm{a}$

Mathematical model for off design condition

$\mathrm{m}_{\mathrm{f}} \frac{d P}{d \mathrm{PR}} * \mathrm{CV}=\mathrm{P}_{\mathrm{R}}+\mathrm{m}_{\mathrm{w}} \mathrm{C}_{\mathrm{pw}}\left[\left(\mathrm{t}_{\mathrm{si}}+\frac{d P}{d \mathrm{PR}} \Delta \mathrm{t}_{\mathrm{j}}\right)-\mathrm{t}_{\mathrm{si}}\right]+---1 \mathrm{~b}$

$\mathrm{m}_{\mathrm{g}} \frac{d P}{d \mathrm{PR}} \mathrm{C}_{\mathrm{pg}}\left(\mathrm{t}_{\mathrm{g}} \frac{d P}{d \mathrm{PR}}-\mathrm{t}_{\mathrm{a}}\right)$

At $\mathrm{P}=\mathrm{P}_{\mathrm{R}}$

$\mathrm{m}_{\mathrm{f}}^{*} \mathrm{CV}=\mathrm{P}+\mathrm{m}_{\mathrm{w}} \mathrm{C}_{\mathrm{pw}}\left(\Delta \mathrm{t}_{\mathrm{j}}\right)+\mathrm{m}_{\mathrm{g}} \mathrm{C}_{\mathrm{pg}}\left(\mathrm{t}_{\mathrm{g}}-\mathrm{t}_{\mathrm{a}}\right)$

$\left(\Delta \mathrm{t}_{\mathrm{j}}\right)_{\mathrm{R}}=\frac{\mathrm{mf} * \mathrm{CV}-\mathrm{P}-\mathrm{mgCpg}(\mathrm{tg}-\mathrm{ta})}{\mathrm{mwCpw}}$

For Exhaust heat recovery unit (EHRU),the model (eq 3a)assumes the effectiveness as unity. For off design conditions the model given in eq 3 should be used. Knowing the air fuel ratio variation with load could help arrive at the temperature $\mathrm{t}_{\mathrm{w} 2}$ at part load(eq $3 \mathrm{~d}$ ).

Mathematical model for Rated Condition

$\mathrm{m}_{\mathrm{w}} \mathrm{C}_{\mathrm{pw}}\left(\mathrm{t}_{\mathrm{w} 2}-\mathrm{t}_{\mathrm{w} 1 \mathrm{R}}\right)=\mathrm{m}_{\mathrm{g}} \mathrm{C}_{\mathrm{pg}}\left(\mathrm{t}_{\mathrm{g} 2}-\mathrm{t}_{\mathrm{g} 1}\right) \quad---3 \mathrm{a}$

Mathematical model for off design condition

$\mathrm{m}_{\mathrm{w}} \mathrm{C}_{\mathrm{pw}}\left(\mathrm{t}_{\mathrm{w} 2}-\mathrm{t}_{\mathrm{w} 1}\right)=\mathrm{m}_{\mathrm{g}} \frac{d P}{d \mathrm{PR}} \mathrm{C}_{\mathrm{pg}}\left(\mathrm{t}_{\mathrm{g} 2}-\mathrm{t}_{\mathrm{g} 1} \frac{d P}{d \mathrm{PR}}\right)$

$\mathrm{m}_{\mathrm{w}} \mathrm{C}_{\mathrm{pw}}\left(\mathrm{t}_{\mathrm{w} 2}-\mathrm{t}_{\mathrm{s} 1}+\frac{d P}{d \mathrm{PR}} \Delta \mathrm{t}_{\mathrm{j}}\right)=\mathrm{m}_{\mathrm{g}} \frac{d P}{d \mathrm{PR}} \mathrm{C}_{\mathrm{pg}}\left(\mathrm{t}_{\mathrm{g} 2}-\mathrm{t}_{\mathrm{g} 1} \frac{d P}{d \mathrm{PR}}\right) \quad---3 \mathrm{c}$

$\mathrm{t}_{\mathrm{w} 2}=\frac{\left[\mathrm{mg} \frac{d P}{d \mathrm{PR}} \operatorname{Cpg}\left(\frac{d P}{d \mathrm{PR}} \operatorname{tg} 2-\operatorname{tg} 1\right)\right]}{(\mathrm{mwCpw})}$

At $\mathrm{P}=\mathrm{P}_{\mathrm{R}}$ 
$\mathrm{t}_{\mathrm{w} 2 \mathrm{R}}=\frac{[\operatorname{mgCpg}(\operatorname{tg} 2-\operatorname{tg} 1)]}{(\mathrm{mwCpw})}+\mathrm{t}_{\mathrm{w} 1}$

For Hot Water Storage unit, the storage volume decides the value of $\mathrm{m}_{\mathrm{s}}$. Eq $4 \mathrm{a}$ calculates the storage temp for rated conditions while eq $4 \mathrm{~b}$ is the model for part load conditions. Eq 5 is the final storage temperature after known time interval for a given initial temperature.

Mathematical model for Rated Condition

$\mathrm{m}_{\mathrm{w}} \mathrm{C}_{\mathrm{pw}}\left(\mathrm{t}_{\mathrm{w} 2 \mathrm{R}}-\mathrm{t}_{\mathrm{si}}\right)+\mathrm{m}_{\mathrm{h}} \mathrm{C}_{\mathrm{ph}}\left(\mathrm{t}_{\mathrm{ho}}-\mathrm{t}_{\mathrm{hi}}\right)=\mathrm{m}_{\mathrm{s}} \mathrm{C}_{\mathrm{p}}\left(\mathrm{t}_{\mathrm{sf}}-\mathrm{t}_{\mathrm{si}}\right) \quad---4 \mathrm{a}$

Mathematical model for off design condition

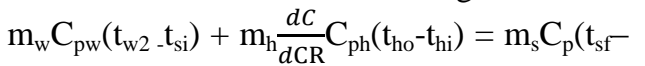

$\left.\mathrm{t}_{\mathrm{si}}\right) /$ time

At $\mathrm{P}=\mathrm{P}_{\mathrm{R}}$ and $\mathrm{C}=\mathrm{C}_{\mathrm{R}}$

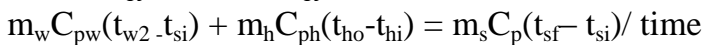

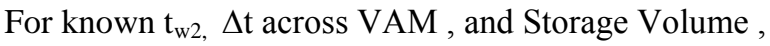
We get,

$\mathrm{t}_{\mathrm{sfR}}=\frac{\mathrm{mwCpw}(\mathrm{tw} 2-\mathrm{tsi})+\mathrm{mhCph}(\text { tho }- \text { thi })}{\mathrm{msCp}} * \mathrm{time}+\mathrm{t}_{\mathrm{si}} \quad---5$

\section{Operating strategy based on storage temperature profile without auxillary heaters}

The mathematical model input are $500 \mathrm{kVa}$ diesel generator parameters (Table 1), the flow rates and hot water generator temperature parameters of 160 TR absorption. It is assumed that the engine generator operates at full load and the cooling load of 160 TR does not vary with time. The model calculates the storage tank temperature with respect to time at full load .The storage volume is taken to be 12000 liters. The heat load on the system is taken to be equivalent to that causing a temperature drop of $3^{0} \mathrm{C}$.

Initially (when the diesel generator and absorption chiller are not in operation) the storage temperature of the water in the tank would be ambient. When the diesel generator starts the temperature of the storage tank would rise at a rate proportional to the heat recovered in engine body and exhaust gases. Since we assume that the engine operates at full load, the gain in temperature would remain constant (Ts-Tsi) though the storage temperature would change as Tsi changes. Thus there is a variation of Ts with respect to time as seen in Fig 2. When the storage temperature reaches an minimum allowable hot water temperature to generator of absorption chiller (say $90.6^{\circ} \mathrm{C}$ which is the required input temperature to absorption chiller considered here) the absorption chiller would be in on mode. The system can now switch over to absorption chiller(cogeneration cooling mode) as a result of which the rate of rise of storage water temperature would decrease. Nevertheless the storage temperature does increase resulting in reaching a temperature which is a upper limit of allowable hot water temperature at generator inlet (say about $95{ }^{\circ} \mathrm{C}$ ). When this higher temperature is reached, the system should switch to trigeneration mode (where the hot water is removed for heating demand).As a result, the temperature of storage water would now start decreasing at a rate proportional to heating $\operatorname{load}\left(\right.$ Here by $\left.3^{0} \mathrm{C}\right)$. When the storage temperature reaches upper limit gets back to cogeneration mode.With auxillary heaters, the operating strategy would however be different.The auxillary heaters would see to it that the entire cooling and heating demand would be met for the entire day and all seasons with auxillary maintaining the storage temperature in the desired range.

Table 1. 500 kVa Diesel Generator Parameters

\begin{tabular}{|l|l|l|l|l|}
\hline Percentage Loading & 25 & 50 & 75 & 100 \\
\hline Exhaust gas temperature & 272 & 375 & 445 & 500 \\
\hline Exhaust gas flow rate kg/h & 1247 & 1494 & 1817 & $\begin{array}{l}218 \\
0\end{array}$ \\
\hline Fuel consumption in kg/h & 27.5 & 45.5 & 70 & 90 \\
\hline Coolant flow rate in lpm & 440 & 440 & 440 & 440 \\
\hline Coolant temperature difference & 4 & 5 & 9 & 11 \\
\hline
\end{tabular}

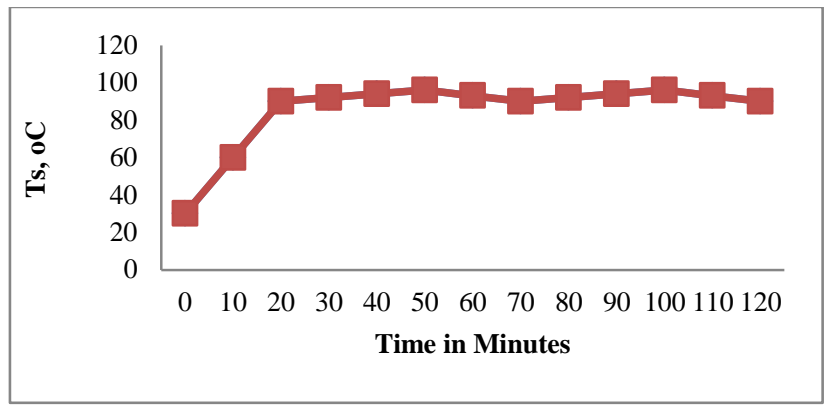

Figure 2.Temperature of storage tank w.r.t time at full load conditions

\section{Concluding Notes}

The proposed trigeneration system includes a thermal storage system recovering heat from engine body as well as exhaust gases. The model includes use of hot water operated absorption chiller which operate at full load with the input from thermal storage tank The mathematical model discussed calculates the storage water temperature which varies with time both for part load as well as full load. The paper illustrates this model for full load operation with $500 \mathrm{kVa}$ Diesel generator and $160 \mathrm{TR}$ chiller. This temperature variation is kept within an allowable range of absorption chiller operation by the proposed operating strategy. The proposed system therefore meets power and cooling demand continuously while alternating between trigeneration and cogeneration cooling mode. It is proposed to evolve an operating strategy based on storage water temperature even under part load conditions. With auxillary heaters, the storage temperature could be maintained constant or within temperature range while simultaneously meeting cooling and heating demand.

\section{References}

Bassols J., Kuckelkorn B., Langreck J., Schneider R., Veelken H., 2002,Trigeneration in the food industry, Applied Thermal Engineering , 22, 595-602. 
J. Godefroy, R. Boukhanouf, S. Riffat, 2007, Design, testing and mathematical modelling of a small-scale CHP and cooling system (small CHP-ejector trigeneration), Applied Thermal Engineering 27, 68-77.

Kyle Gluesenkamp, Yunho Hwang, Reinhard Radermacher, 2013, High efficiency micro trigeneration systems, Applied Thermal Engineering 50, 1480-1486.

Piero Colonna , Sandro Gabrielli, 2003, Industrial trigeneration using ammonia-water absorption refrigeration systems, Applied Thermal Engineering 23, 381-396.

Galip Temir, Durriye Bilge, 2004, Thermoeconomic analysis of a trigeneration system, Applied Thermal Engineering 24, 26892699.

Armando Huicochea, Wilfrido Rivera, Geydy Gutiérrez-Urueta, Joan Carles Bruno, Alberto Coronas, 2011, Thermodynamic analysis of a trigeneration system consisting of a micro gas turbine and a double effect absorption chiller, Applied Thermal Engineering 31, 3347-3353.
Ziher D., Poredos A., 2006, Economics of a trigeneration system in a hospital, Applied Thermal Engineering 26, 680-687.

E. Teopa Calva, M. Picon Nunez, M.A. Rodriguez Toral, 2005, Thermal integration of trigeneration systems, Applied Thermal Engineering 25, 973-984.

Shelar Mahesh, Bagade Sunil, Kulkarni Govind, 2009a, Waste heat recovery possibilities for a typical Indian hospital, Proceedings of International conference on advances in mechanical engineering, 36-40, SVNIT Surat, India.

Shelar Mahesh, Bagade Sunil,Kulkarni Govind,2009b,An approach for selection of engine based cogeneration-cooling system, Proceedings of National Conference on Renewable Energy,Jodhpur,89-92,NIT,Jodhpur,India.

Shelar Mahesh, Bagade Sunil, Kulkarni Govind, 2009c, Trigeneration for a typical Indian Hospital: An assessment considering compulsory load management scenario, Proceedings of International conference on advances in energy research, 338-342, IIT Bombay, India. 